
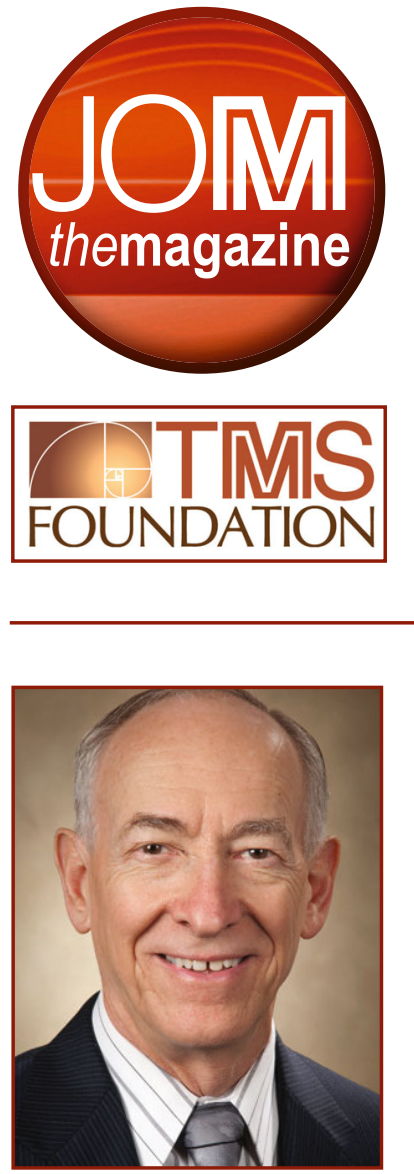

Garry W. Warren

\title{
A Challenge to TMS Members: Meet Your Match
}

\author{
Garry W. Warren \\ Chair, TMS Foundation Board of Trustees
}

\section{TMS Foundation: growth through giving}

This regular JOM feature provides updates on TMS Foundation activities, as well as news on opportunities for TMS Foundation support and engagement. Visit the Foundation website at www.TMSFoundation.org to learn more.

I am consistently amazed at the energy and wisdom of those just starting out in our profession. I have taught and worked beside students and young researchers for more than 35 years. Many times, I have taken significant steps forward in my own thinking and understanding by looking at a project or problem through their eyes and applying the fresh perspectives that they bring to the field.

Much has certainly been written and said about the importance of youth to science and engineering, including our own minerals, metals, and materials disciplines. From my own experience, I know this is true. I also believe that building a successful career requires more than studying hard and mastering technical skills. Providing tools, experiences, and motivation to young professionals to realize their potential as leaders and contributors is a critical, and often neglected, professional development space. That's why the TMS Foundation has made it a mission to fill that

\section{Fast Facts about the 2016 Annual Appeal}

Goal: $\$ 100,000$

Double Your Impact: The first $\$ 30,000$ donated during the campaign will be matched, dollar for dollar, through a challenge supported by Foundation leaders.

\section{Deadline: December 31, 2016}

Employer Match: Register The Minerals, Metals \& Materials Society for an employer match with your company. TMS (EIN \#: 25-1484913) is a qualified 501(c)(3) tax-exempt organization.

Donate Online: Visit www.TMSFoundation.org/Contribute.

Note Our New Mailing Address: TMS Foundation, 5700 Corporate Drive, Suite 750, Pittsburgh, PA 15237.

More Information: Contact Mary Samsa, TMS Foundation \& Public Affairs Manager, at (724) 814-3130 or msamsa@tms.org

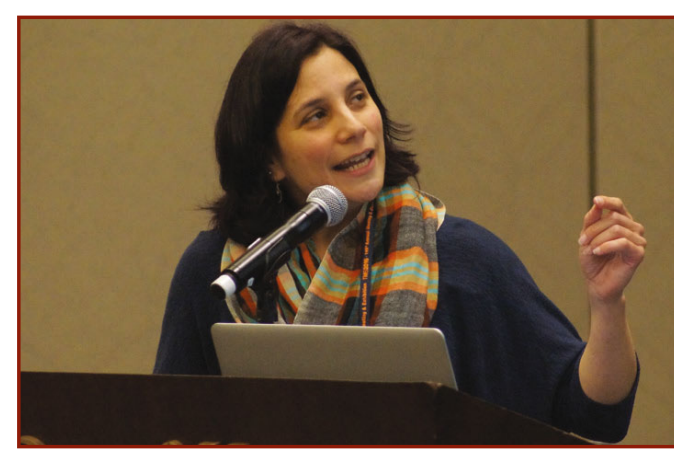

Elif Ertekin, assistant professor, University of Illinois, and 2016 TMS Early Career

Faculty Fellow, makes a point during her tutorial luncheon lecture. The fellowship is supported by the TMS Foundation.

need since 1993 .

Here is just a quick look at what the Foundation has accomplished in just 2016 alone:

- 12 promising students received TMS Division Scholarships to support their academic pursuits and professional growth.

- 33 students attended the TMS 2016 Annual Meeting \& Exhibition (TMS2016) or Materials Science \& Technology, thanks to TMS Foundation Travel Grants.

- 23 TMS members gained exposure for their work and expanded their networks as TMS Young Leaders Professional Development Awardees.

- 8 TMS members attended the Emerging Leaders Alliance Capstone Program, with support by the TMS Foundation, for preparation in addressing challenges in complex business environments.

- 2 exceptional young faculty members were able to share their work more 
broadly as TMS Foundation Early Career Faculty Fellows.

- 1 TMS Foundation International Scholar traveled to Japan to develop scientific collaborations across cultures.

Now, consider the hundreds of awards and scholarships that the Foundation has conferred over the years-240 Division Scholarships and 250 Young Leaders Professional Development Awards, for starters. Many, many of those individuals have gone on to do incredible things, both as professionals and TMS members, and often point to the recognition and support of the TMS Foundation as a launching point for their success.

So yes, while much has indeed been written and said about developing the next generation of science and engineering professionals, the TMS Foundation has actually done something about it and done it well. But, to continue that good work - and expand its initiatives for greater impact - the Foundation needs TMS members who are established in their

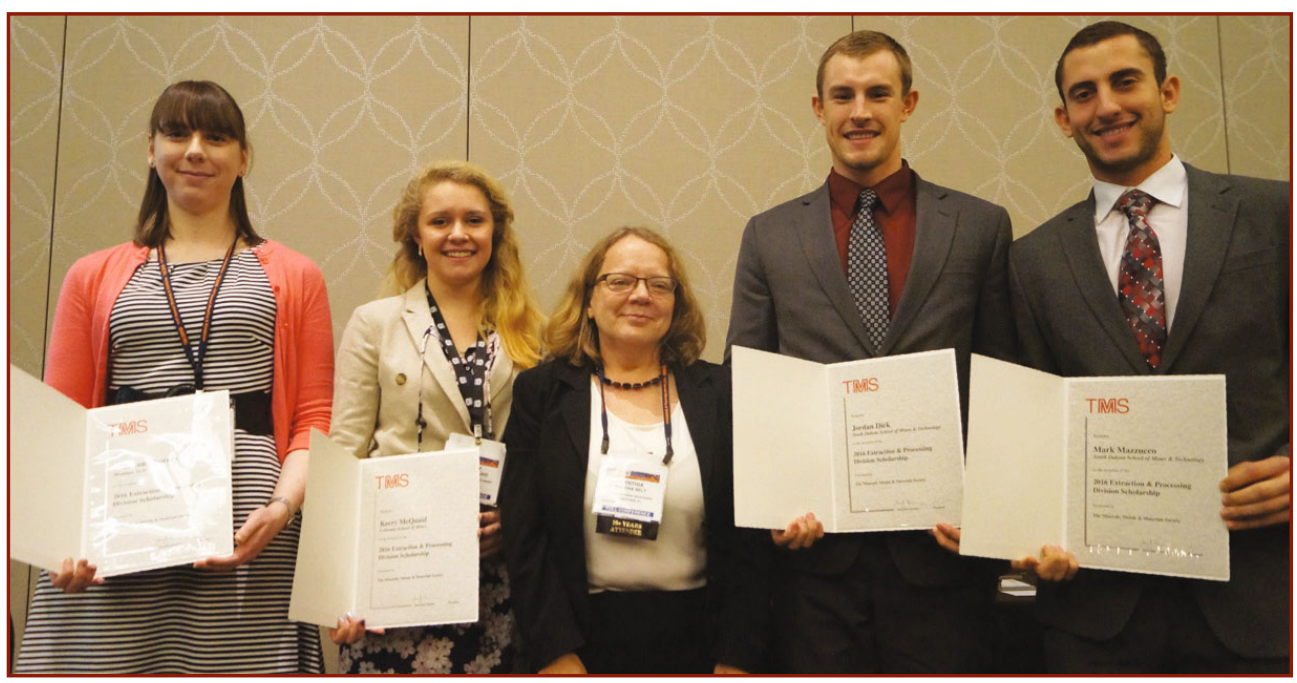

Cynthia K. Belt (center), Vice Chair, Extraction \& Processing Division (EPD), did the honors of presenting the EPD's student scholarships at the TMS 2016 Annual Meeting \& Exhibition (TMS2016 ) (left to right): Maureen Chorney, Montana Tech of the University of Montana; Kerry McQuaid, Colorado School of Mines; Jordan Dick, South Dakota School of Mines and Technology; and Mark Mazzucco, South Dakota School of Mines and Technology.

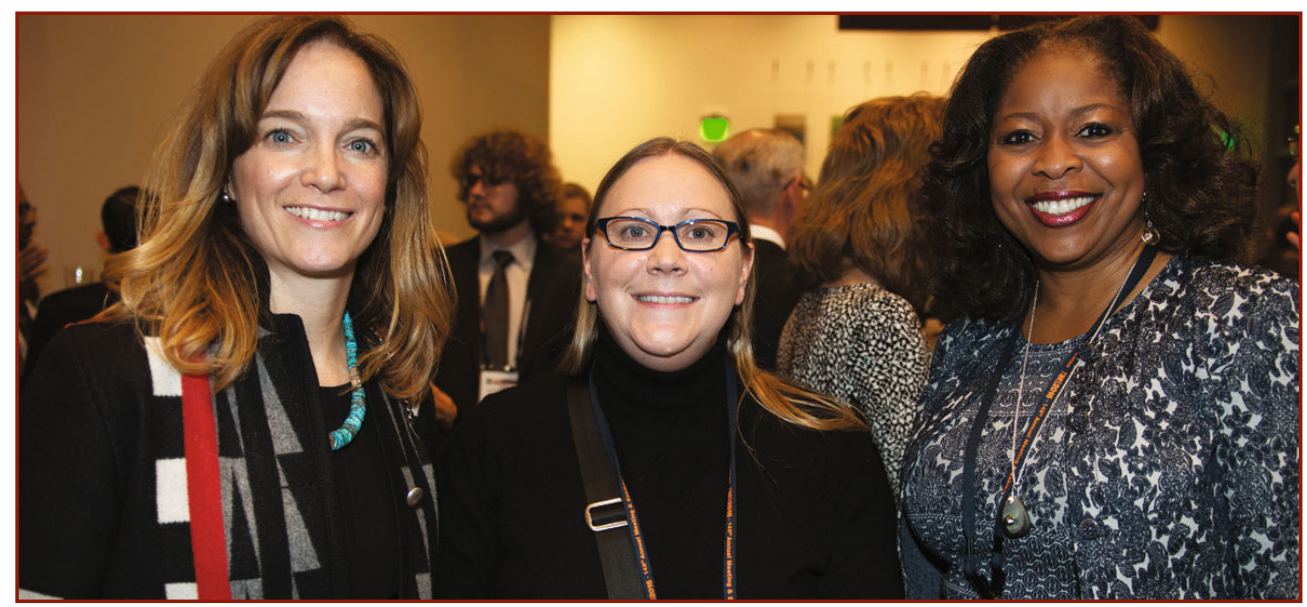

Past TMS Young Leaders Professional Development Awardees have gone on to make tremendous technical, scientific, and professional contributions. Pictured are three of them catching up at TMS 2016 (left to right): Ellen Cerreta (2004 Young Leader), group leader, Materials in Radiation and Dynamic Extremes Group, Los Alamos National Laboratory, and Structural Materials Division Chair, TMS Board of Directors; Amy Clarke (2008 Young Leader), Associate Professor, Colorado School of Mines, and Member and Student Development Chair, TMS Board of Directors; and Viola Acoff (1998 Young Leader), Associate Dean for Undergraduate and Graduate Programs, University of Alabama, Tuscaloosa.

\section{TMS Foundation Board of Trustees}

Chair:

Garry W. Warren

Professor Emeritus,

University of Alabama

Past Chair:

Robert H. Wagoner

Professor Emeritus,

The Ohio State

University

\section{Executive Committee \\ Representative:}

Stanley M. Howard

Professor

South Dakota School of Mines and Technology

Trustees:

Carl M. Cady

Technical Staff Member,

Los Alamos National

Laboratory

Hani Henein

Professor,

University of Alberta

Edward D. Herderick Additive Technologies

Leader,

GE Corporate Supply

Chain and Operations

Elizabeth A. Holm

Professor,

Carnegie Mellon

University

Alexander R. Scott

Retired TMS Executive

Director

David A. Shifler

Program Officer

Office of Naval Research

Secretary:

James J. Robinson

TMS Executive Director 


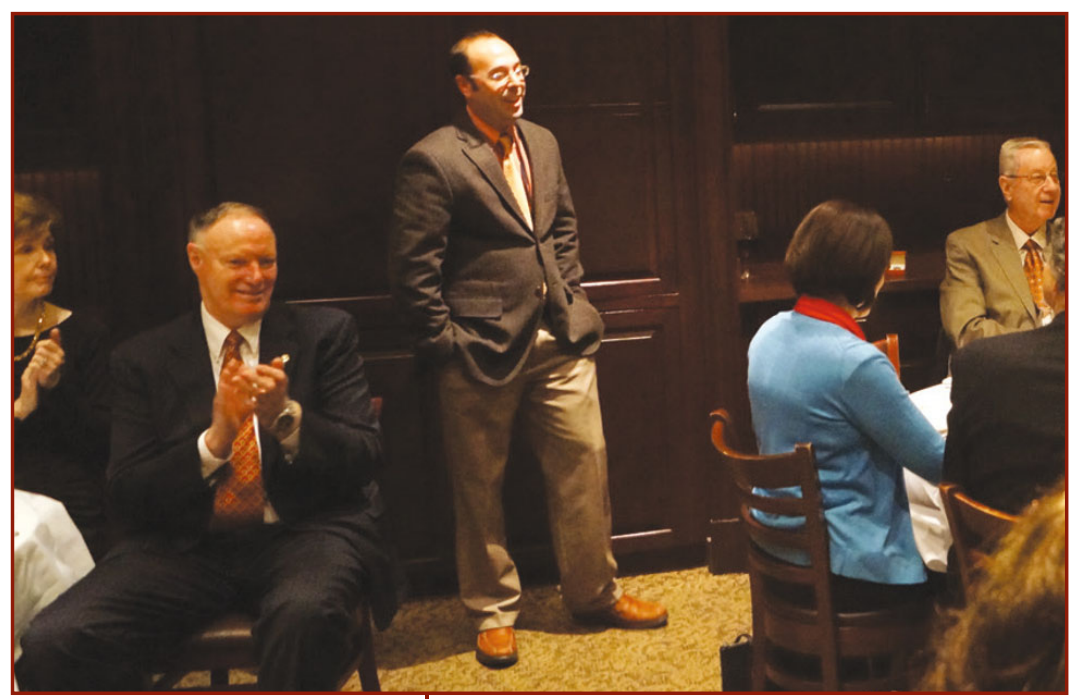

Kyle Brinkman (standing), associate professor, Clemson University, spoke at the TMS Foundation Donor Recognition Event at TMS2016 on the impact that the TMS Foundation has had on his career as a recipient of the 2011 Young Leaders Professional Development Award and 2015 FEMS/TMS Young Leaders International Scholar Award. careers to step up and make sure the next generation can advance.

That is why I am encouraging all TMS members to contribute to the TMS Foundation 2016 Annual Appeal. This year, we have set a goal of $\mathbf{\$ 1 0 0 , 0 0 0}$, with every cent needed to sustain and grow the Foundation's support to our TMS members in the most critical stages of their career development.

To keep us on pace to reach that goal, we have had several TMS Foundation leaders come forward to pool their resources for a $\$ \mathbf{\$ 3 0 , 0 0 0}$ challenge match. This means that donors who contribute to the first $\$ 30,000$ raised in the 2016 Annual Appeal will have their donations matched, dollar for dollar. (See sidebar articles.)

Any contribution, great or small, means that you have directly made a difference in the professional life of an early career TMS member:

- If 10 people give $\$ \mathbf{5 0}$, the TMS Foundation can send a student to the TMS 2017 Annual Meeting on a travel grant.

- If 20 people give $\$ \mathbf{1 0 0}$, a student will receive academic assistance through a TMS Division Scholarship.

- If 3 people give $\mathbf{\$ 2 0 0}$, the TMS Foundation can support Emerging Leaders Alliance training for a future industry leader.

- If 6 people give $\$ \mathbf{5 0 0}$, the TMS Foundation can boost the career of a promising TMS member with a Young Leaders Professional Development Award.

Time and again, TMS members have told me that they value the Foundation, what it does, and what it stands for. I am deeply appreciative of those who have turned those good intentions into action and supported the Foundation generously, particularly during our last two years of revitalization. To all other TMS members_-please make this the year that you make an impact on the future leaders of our profession by supporting the TMS Foundation.

\section{Challenge Match Supporters}

Thank you to the following individuals who made the $\$ 30,0002016$ TMS Foundation Annual Appeal Challenge Match possible:

\section{Martin and Lucinda Glicksman Lead Donors}

The first and still the only members of the TMS

Foundation Diamond Society, the Glicksmans have been tireless champions of the TMS Foundation since it was founded.

\section{Robert and Robyn Wagoner \\ Lead Donors}

Robert $\mathrm{H}$. Wagoner led the charge to revitalize the TMS Foundation, assuming the role of Board of Trustees chair in 2013 to oversee the early stages of that effort with a restructured Board of Trustees, a new financial management approach, and proactive fundraising strategies. The Wagoners are also inaugural members of the TMS Foundation Gold Society.

\section{Garry W. Warren}

Garry Warren is the current TMS Foundation Board of Trustees Chair and was instrumental in planting the seeds for the Foundation's revitalization while he served as the 2011 TMS President. Warren is a member of the TMS Foundation Gold Society.

\section{Stanley M. Howard}

Stanley Howard is a Trustee of the TMS Foundation Board, as well as the 2016 TMS President. He has been a long-time supporter of the Foundation and is an inaugural TMS Foundation Silver Society member.

The first $\$ 30,000$ raised during the 2016 TMS Foundation Annual Appeal will be matched, dollar for dollar, by this challenge. Make an online donation today at www.TMSFoundation.org/Contribute or mail your donation to: TMS Foundation, 5700 Corporate Drive, Suite 750, Pittsburgh, PA 15237.

TMS is a qualified 501 (c)(3) tax-exempt organization and donations are deductible to the full extent of the law in the United States.

For additional information on the Foundation, including the Diamond, Gold, and Silver Honorific Societies, and the new Titanium and Platinum Honorific Societies, visit the Foundation website at www.TMSFoundation.org. 